\begin{tabular}{|c|c|c|c|}
\hline Plant & Fine soil & Medium soil & Coarse soil \\
\hline 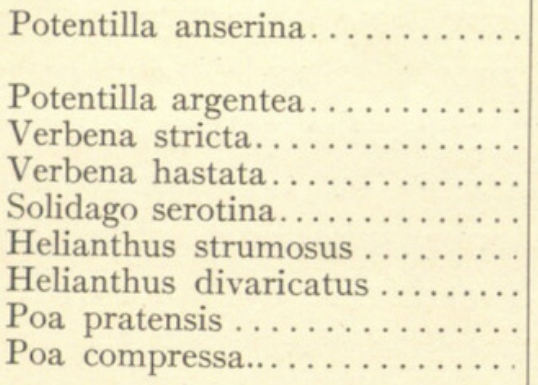 & $\begin{array}{r}20-23 \\
20-23 \\
8-15 \\
14-19 \\
42-45 \\
18-23 \\
22-28 \\
15-20 \\
28-40\end{array}$ & $\begin{array}{c}8-10 \\
4-5 \\
2-5 \\
5-8 \\
\text { IO-17 } \\
3-12 \\
\text { I } 4-\text { I9 } \\
\text { dead } \\
\text { nearly dead }\end{array}$ & $\begin{array}{c}6-8 \\
(3 \text { out of } 4 \text { dead) } \\
3-6 \\
2-4 \\
2-3 \\
\text { ro-12 } \\
\text { ro-1 I } \\
\text { 10-17 } \\
\text { dead } \\
\text { dead }\end{array}$ \\
\hline
\end{tabular}

While the above table is strikingly significant in showing relative size, and therefore relative rate of growth, it does not express at all the equally prominent features of comparative size and numbers of leaves, the presence or absence of runners, the wealth or scarcity of flowers, and all the features which go to make one plant vigorous and the other barely existing.

It will be realized at once that the experiment here described offers somewhat conclusive evidence in favor of the above-mentioned hypothesis of one of the present authors (loc. cit.), as well as of that recently expressed by Whitney and Cameron ${ }^{3}$ in regard to agricultural plants. A fuller discussion and analysis of the conditions here dealt with would be out of place in this announcement, the purpose of the latter being only to state the facts in regard to the experiment. Further work along these lines is in progress.-Burton Edward Livingston and Gerhard H. Jensen, The University of Chicago.

\title{
A NEW GILIA.
}

Gilia sapphirina, sp. nov. (HugeLIA).-Erect, paniculately branched from the base, the branches slender, sparsely leaved, the main stem and some of the principal branches inclined to be tortuous, viscid-glandular throughout, $30^{\mathrm{cm}}$ high or more: leaves (all but the uppermost) simple, subterete, tipped with a white bristle, often purplish, $\mathrm{I}-5^{\mathrm{cm}}$ long; uppermost leaves with two very short bristle-tipped divisions at base: flowers solitary or capitate in few-flowered clusters from most of the leaf axils, even those near the base of the stem, either sessile or on peduncles $10-15^{\mathrm{mm}}$ long; involucral bracts broadly ovate and simple or 3 -lobed, membranous on each side of the broad green rib, glandular and clothed with very few woolly hairs calyx $8^{\mathrm{mm}}$ long, the divisions one-third the entire length, the central green rib $0.75^{\mathrm{mm}}$ wide, slightly narrower than the membranous

3 Whitney, M., and Cameron, F. K., The chemistry of the soil as related to crop production. U. S. Dept. of Agric., Bureau of Soils, Bull. $22: 72$. $19 \circ 3$. 
fold between, glandular-puberulent and viscid, not at all lanate: corolla salverform, the tube $4^{\mathrm{mm}}$ long, slightly surpassing the spine-tipped triangular divisions of the calyx; border sapphire blue, throat yellowish, lobes broadly obovate to orbicular, retuse at apex, $7^{\mathrm{mm}}$ wide, $10^{\mathrm{mm}}$ long; filaments and anthers white, exserted about $7^{\mathrm{mm}}$, the anthers oblong, sagittate, $3^{\mathrm{mm}}$ long: style longer than the filaments but not equaling the anthers; stigmas 3 or 4 , short, narrowly linear: capsule barely surpassing the calyx lobes, usually with only one seed in each cell, the other ovules present but abortive.

Type collected November I903 by Mrs. Blanche Trask, in the San Jacinto Mountains, California. Specimen 2630 of H. M. Hall's collection from the same mountains, distributed as G. virgata Steud., is the same but is much younger than Mrs. Trask's specimen. Neither can be properly referred to G. virgata if the figure in Hooker's Icones 200 represents that species. The paniculate instead of virgate habit, the glandular instead of white-lanate pubescence, the distinct and broad membranous sinus of the calyx, the broad retuse lobes of the corolla, the few seeds in the capsule, all serve to distinguish them.-Alice EAstwood, California Academy of Sciences. San Francisco. 


\section{$2 \mathrm{BHL}$ Biodiversity Heritage Library}

Eastwood, Alice. 1904. "A New Gilia." Botanical gazette 38(1), 71-72. https://doi.org/10.1086/328523.

View This Item Online: https://www.biodiversitylibrary.org/item/95711

DOI: https://doi.org/10.1086/328523

Permalink: https://www.biodiversitylibrary.org/partpdf/223170

\section{Holding Institution}

Missouri Botanical Garden, Peter H. Raven Library

\section{Sponsored by}

Missouri Botanical Garden

\section{Copyright \& Reuse}

Copyright Status: Public domain. The BHL considers that this work is no longer under copyright protection.

This document was created from content at the Biodiversity Heritage Library, the world's largest open access digital library for biodiversity literature and archives. Visit BHL at https://www.biodiversitylibrary.org. 